\title{
ARTYKUŁY
}

Klio. Czasopismo poświęcone dziejom Polski i powszechnym

PL ISSN 1643-8191, t. 53 (2)/2020, s. 107-132

(c) (1) $\Theta$

http://dx.doi.org/10.12775/KLIO.2020.021

AnNa OdRZYwolsKa*

\section{Praktyki magiczne w XVI w. i ich kontekst kulturowy}

\section{Magic in the $16^{\text {th }}$ century and its cultural background}

Streszczenie: Podstawę źródłową omówienia tego problemu badawczego stanowią polskie renesansowe zielniki autorstwa Stefana Falimirza, Hieronima Spiczyńskiego, Marcina Siennika, Marcina z Urzędowa oraz Szymona Syreniusza. Miały one za zadanie przekazywać popularną wiedzę medyczną, były kierowane do specjalistów trudniących się leczeniem bądź wytwarzaniem leków, ale też do zwykłych ludzi. Analiza tego materiału źródłowego pokazała, że magia była obecna w życiu codziennym oraz znajdowała umocowanie i akceptację u autorów zielników, którzy prezentując pewne rytuały magiczne, byli przekonani o ich skuteczności. Do działań magicznych można zaliczyć pewne ryty, które opierały się na przeświadczeniu o konieczności wykonania pewnych konkretnych czynności, aby w konsekwencji nadać medykamentowi siłę działania.

Abstract: The paper analysis Polish Renaissance herbaria prepared by Stefan Falimirz, Hieronim Spiczyński, Marcin Siennik, Marcin from Urzędów, and Szymon Syreniusz.

Instytut Historii, Wydział Humanistyczny Uniwersytetu Humanistyczno-Przyrodniczego im. Jana Długosza w Częstochowie, 42-200 Częstochowa, al. Armii Krajowej 36a, a.odrzywolska@ujd.edu.pl, ORCID: 0000-0003-2833-7820. 
Their main goal was to disseminate popular medical knowledge. These herbaria were addressed to specialist, physicians and producers of curing mixtures, however common people were also interested in using them. This source material reveals that magic was present in everyday life, and was legitimised by authors of herbaria, who - while presenting some magical rituals - were certain on their effectiveness.

Słowa kluczowe: magia, rytuały magiczne, zielniki renesansowe

Keywords: magic, magic rituals, renaissance herbaria

W śród badaczy nadal aktualną kwestią jest próba rozstrzygnięcia problemu, czy przekonanie o właściwościach magicznych roślin należy wiązać z religią słowiańską, ponieważ istnieje inna teoria - uznająca, że łączy się ono z tradycją łacińską, a więc obcą. Naukowe rozważania dotyczą również kwestii nierozstrzygalnej - czy przeświadczenie o istnieniu roślin czarodziejskich trafiło do świadomości ludzi z zielników pisanych na podstawie źródeł należących do europejskiej kultury antycznej i średniowiecznej. Nie wyklucza się też, że nastąpił proces odwrotny - wierzenia ludowe stały się inspiracją dla autorów herbarzy ${ }^{1}$. Analiza polskich zielników renesansowych, które będą dla mnie podstawowym źródłem opracowania zagadnienia, pozwoli przyjrzeć się temu problemowi badawczemu.

Niekiedy trudno odróżnić magię leczniczą od medycyny, często przepisy medyczne były bowiem tak konstruowane, że zawierały rytuały podobne do tych stosowanych przez ludzi trudniących się czarowaniem ${ }^{2}$. Podobnie rzecz wyglądała ze skutecznością preparowanych medykamentów, które

1 Por. J. Rostafiński, Zielnik czarodziejski to jest zbiór przesądów o roślinach, Kraków 1893, s. 1-2; R. W. Barwiński, Studia o literaturze ludowej ze stanowiska historycznej i naukowej krytyki, t. 2, Poznań 1854, s. 82-90.

2 Omówienie pojęcia czarów i magii: J. Adamczyk, Czary i magia w praktyce sądów kościelnych na ziemiach polskich w późnym średniowieczu (XV-potowa XVI wieku), w: Karolińscy pokutnicy i polskie średniowieczne czarownice. Konfrontacja doktryny chrześcijańskiej z życiem spoteczeństwa średniowiecznego, „Fasciculi Historici Novi” 2007, t. 7, s. 91-95; Z. Krótki, Biata magia w leksyce dawnej polszczyzny, „Socjolingwistyka” 2015, t. 29, s. 301-311. 
nierzadko były dobierane metodą doświadczalną. W praktyce ludowej opisanej w zielnikach zdecydowanie przeważają przepisy zaliczane do magii białej, której zadaniem było pomaganie ludziom.

\section{Podstawa źródłowa. Cel i metoda badawcza}

Podstawowymi źródłami stały się dla mnie polskie zielniki renesansowe, do których zaliczyłam - obok herbarzy autorstwa Stefana Falimirza ${ }^{3}$, Hieronima Spiczyńskiego ${ }^{4}$, Marcina Siennika ${ }^{5}$, Marcina z Urzędowa ${ }^{6}$ - również zielnik Szymona Syreniusza ${ }^{7}$, pisany przez ponad 30 lat i wydany ostatecznie w 1613 r. Uwzględniłam również dzieło Piotra Krescencjusza, mimo

3 S. Falimirz, $O$ ziolach y o moczy gich. O Paleniu wodek z ziol. O Oleykoch przyprawianiu. O Rzeczach zamorzkich. O Zwierzetach, o Ptaczech, y o Ribach. O Kamieniu drogim. O Vrinie, O Pulsie, $Y$ o inych znamionach. O Rodzeniu dziatek. O Naucze gwiazdeczney. O stawianiu baniek. Yo puszczaniu krwie. O Rzadzeniu czasu powietrza morowego. O Lekarsztwach doswiadczonych na wiele niemoczy. O Naucze Barwierzkiey, Kraków 1534.

${ }^{4} \mathrm{H}$. Spiczyński, O Ziolach tutecznych y zamorskich y o mocy ich, a kthemu kxegi lekarskie wedle regestru napisanego wszem wielmi użyteczne [...], Kraków 1542.

5 M. Siennik, Herbarz to jest Ziót tutecznych, postronnych y zamorskich opisanie: co za moc maia, a iako ich vżywać tak ku przestrzeżeniu zdrowia ludzkiego, iako ku vzdrowieniu rozmaitych chorob: Teraz nowo, wedle Herbarzow dźisieyszego wieku, y inych zacnych Medykow poprawiony. Przydano Aleksego Pedemontana Ksiegi ośmiory, o tajemnych a skrytych Lekarstwiech [...], Kraków 1568.

6 Marcin z Urzędowa, Herbarz Polski to iest o przyrodzeniu ziót y drzew rozmaitych, y innych rzeczy do lekarzy należących, Ksiegi dwoje, druk. Łazarzowa, Kraków 1595.

7 Sz. Syreniusz, Zielnik Herbarzem z ięzyka Eacinskiego zowia. To iest Opisanie wtasne imion, ksztattu, przyrodzenia, skutkow, y mocy Zioł wszelakich Drzew, Krzewin y korzenia ich, Kwiátu, Owocow, Sokow Miasg, Zywic y korzenia do potraw zaprawowania. Tak Trunkow, Syropow, Wodek, Likworzow, Konfitor, Win rozmaitych, Prochow, Soli zziot czynioney; Maści, Plastrow. Przytym o Ziomach y Glinkach rożnych: o Kruscach Pertach y drogich Kamieniach. Tez o zwierzetach czworonogich, czotgajacych Ptastwie, Rybach y tych wszystkich rzeczach ktore od nich pochodza od DIOSCORIDA z przydaniem y dostatecznym doktadem z wielu innich o tey materiey piszacych, z potożeniem wtasnych figur dla snadnieyszego ich poznania a y używania ku zatrzymaniu zdrowia tak ludzkiego iako bydlecego y chorob przypadtych odpedzenia, z wielkiem uważaniem y rozsadkiem Polskiem iezykiem zebrany y na osmiero ksiag roztożony Ksiega lekarzom, Aptekarzom, Cyrulikom, Barbirzom, Roztrucharzom, końskiem lekarzom, Mastalerzom Ogrodnikom Kuchmistrzom, kucharzom, Synkarzom, Gospodarzom, 
tego, że autor wywodził się z kręgu kultury włoskiej i żył w okresie średniowiecza. Odwołanie się do tego materiału źródłowego uznałam za słuszne, gdyż źródło to zostało przetłumaczone na język polski w 1571 r. i wówczas weszło do szerszego obiegu czytelniczego w Polsce ${ }^{8}$. Podobny zamysł przyświecał mi w związku z wykorzystaniem Tajemnic Aleksego Pedemontana, dzieła wydanego jako suplement do zielnika Marcina Siennika. Tutaj również znalazło się nieco informacji na temat roślin i praktyk magicznych9. Ponadto mimo tego, że temat zawężono do XVI w., został uwzględniony kiedy zachodziła taka potrzeba - materiał źródłowy, który wychodzi poza te ramy chronologiczne ${ }^{10}$.

W zakres pola badawczego weszły praktyki magiczne z zastosowaniem roślin leczniczych, metody mające na celu uleczenie ludzi z czarów oraz sposoby na zapobieganie urokom. Niekiedy trudno rozróżnić, czy mamy do czynienia ze zwykłą medycyną ludową, czy już z magią ziołoleczniczą. Podobnie, pojawiają się problemy przy rozróżnieniu, czy mamy do czynienia z magią pomocniczą bądź szkodliwą. W związku ze specyfiką materiału źródłowego wiele aspektów związanych z omawianą problematyką nie mogło zostać przeanalizowanych. Zielniki zawierają informacje na temat

Mamkom, Paniom Pannom y tym wszytkim ktorzy sie kochaia y obieruia w lekarstwach pilnie zebrane a porsądnie zpisane, Kraków 1613.

${ }_{8}$ P. Crescentyn, O pomnożeniu y rozkrzewieniu w zelakich Pożytkow, kśiag Dwoienaście: Ludźiom Stanu każdego, ktorzyby śį vczćiwym Gospodarftwem bawili, wielce potrzebne a pożyteczne, Kraków 1571.

9 DéSecreti del Reverendo donno Alessio Piemontese - Sekrety wielebnego Aleksego z Piemontu wyszły drukiem w Wenecji 1555 r. i wkrótce zyskały wielką popularność w całej Europie. Dzieło to, przetłumaczone na język polski przez Marcina Siennika, zostało wydane jako dodatek do jego herbarza, który został opublikowany w Krakowie w 1568 r. Trwają dyskusje na temat autora dzieła. Rosnącą popularność zyskuje teza, że za prawdziwego autora należy uznać Girolama Ruscellego, Aleksy Pedemontana to zaś jedynie jego pseudonim; zob. Z. Bela, Polska wersja "Sekretów” Aleksego z Piemontu, „Przekładaniec” 2016, nr 32, s. 297-301. Ten sam uczony we wcześniejszym artykule stał na stanowisku, że Aleksy z Piemontu był postacią autentyczną, był zakonnikiem oraz lekarzem Joanny Aragońskiej zwanej Szaloną, trudnił się też alchemią, żył w drugiej połowie XV w. i pierwszej połowie XVI w.; Z. Bela, Alexego Pedemontana Tajemnice. Monografia, Kraków 1999, s. $275-293$.

${ }^{10}$ J. K. Haur, Sktad abo skarbiec znakomitych sekretów oekonomiej ziemiańskiej, Kraków 1693. 
wykorzystania pewnych roślin do celów magicznych. Brak jednak w nich informacji o tym, w jakim zakresie odbiorcy tych popularnych poradników medycznych wykorzystywali w swoim życiu codziennym te przepisy. Dla badacza ważne jest odnotowanie samego zjawiska w świadomości ówcześnie żyjących ludzi. Wiele mówi to o mentalności i o podejściu do kwestii czarów.

\section{Osoby trudniące się czarami, gusłami i zabobonami}

W zielnikach pojawiają się informacje na temat osób trudniących się rzucaniem czarów i ich odczynianiem, choć nic nie można wnioskować na temat ich pochodzenia społecznego, posiadanej wiedzy czy wyznawanej religii. Syreniusz podał precyzyjną definicję słowa „czarownik”, odwołując się do tradycji starożytnej Grecji ${ }^{11}$. Przy opisie właściwości magicznych poszczególnych ziół można niekiedy znaleźć wzmianki o babach biegłych w czarowaniu albo o „gusłach babskich” 12 . Następstwem „złego urzeczenia bab” mogło być rzucanie uroku na niemowlęta ${ }^{13}$. Z przekazu Aleksego Pedemontana wiadomo, że czarami trudniły się kobiety o podejrzanej reputacji. Niewiasty te rzucały czary wyłącznie na mężczyzn i robiły to dla zwykłej rozrywki ${ }^{14}$. Praktykami magicznymi parały się również „niewiasty czarowne

11 Sz. Syreniusz, op. cit., ks. III, rozdz. 54, k. 735. Opisując właściwości ziela o nazwie „czarownik”, Syreniusz w ten sposób tłumaczył etymologię tego słowa: „[...] to ziele słusznie od nas czarownikiem abo czarnokwitem, jako i od Greków Circea i od Łacinników jest nazwane. Abowiem Circes jako poetowie Greccy bają, była córka Słońca, które jest wszystkich planet ojcem: ta znajomość ziół wszystkich i mocy ich od niego wzięłą, zaczym do czarów takich przyszła, że ludzi przez nie w bestie rozmaite, w kamienie, w drzewa, i w cokolwiek chciała, przemieniła, do czego też jako niektórzy piszą, tego używała, i stąd u nas od czarów tej Circe nazwiska Czarownik dostało, jako też od tej czarownice w łacińskim i w greckim języku Circea to jest, że go ona pierwsza wynalazła i do swych czarów używała”.

12 Ibidem, ks. III, rozdz. 73, k. 765.

13 H. Spiczyński, op. cit., cap. 100 B, list 41v.

${ }_{14}$ Aleksego Pedemontana Ksieggi siedmioro Taiemnic rozmaite nauki $w$ sobie maiace $z$ tacińskiego na polski język teraz nowo przetożone przez Marcina Siennika, ks. 5, rozdz. 3: O leczeniu wstydu, w: M. Siennik, op. cit., list 554. 
i baby z diabłami się obierające” ${ }^{15}$. Czary mogły też być skutkiem „zadania przez złego człowieka”. Nie została tutaj określona płeć, ale wiadomo, że następstwem rzucenia uroku mogło być zalęgnięcie się w człowieku jadowitych węży i robaków ${ }^{16}$. Czary „przez złego człowieka uczynione” mogły też powodować szaleństwo ${ }^{17}$. Spiczyński pisał, że „wielu ludzi prostych [...] wróżki rozmaite i gusła czynią" ${ }^{18}$. Czarami parali się też „mistrzowie zabobonów”, którzy posiadali wiedzę na temat układu planet i ich wpływu na właściwości roślin. Posługiwali się oni różnymi metodami i narzędziami ${ }^{19}$. Także „czarownicy i czarownice, guślarze, [...] zabobonnicy pogańscy jako źli chrześcijanie" pomagali sobie czarami ${ }^{20}$. Znalazłam też notatkę, że to medyk stosował praktyki, które można uznać za magiczne ${ }^{21}$. Jakub Haur nieco później podawał, że osoba, na którą został rzucony czar, mogła sama przeprowadzić rytuał odczarowania przez oddanie moczu na miotłę wykonaną z witek brzozowych oraz chebdu, czyli czarnego bzu ${ }^{22}$. Wydaje się zatem, że odróżniano znachorki, które miały pomagać przez uprawianie białej magii, od czarownic, których zadanie polegało na szkodzeniu ludziom przez współdziałanie z siłami nadprzyrodzonymi ${ }^{23}$.

\section{Czas i sposób pozyskiwania ziół}

Praktyki magiczne obecne w zielnikach sprowadzały się do zespołu rytuałów, mających na celu osiągnięcie określonego efektu. Proces ten był

15 M. Siennik, op. cit., ks. I, cz. I, rozdz. 140, list 106.

16 Sz. Syreniusz, op. cit., ks. I, rozdz. 22, k. 91.

17 Ibidem, ks. IV, rozdz. 140, k. 1241.

18 H. Spiczyński, op. cit., cap. 255 E, list 95.

19 Np. kłącza dzięgielnicy (łac. Angelica magna) przewiercali długim żelaznym prętem; Sz. Syreniusz, op. cit., ks. I, rozdz. 26, k. 105.

20 Ibidem, ks. III, rozdz. 125, k. 847.

21 H. Spiczyński, op. cit., cap. 255 E, list 95.

22 J. K. Haur, op. cit., k. 453: „[...] niech patient oczarowany urynę swoję puszcza, a tak owe zginą y zniszczeją czary, y daley ciału szkodzić nie będą”. Warunkiem skuteczności tego rytuału miało być to, aby wskazana miotła była wepchnięta w ziemię.

23 J. B. Russell, Krótka historia czarownictwa, tłum. J. Rybski, Wrocław 2003, s. 6-17, 55-57. Tutaj znajduje się etymologia i definicja słów „czary” i „czarownica”. 
dodatkowo wspomagany przez wypowiadanie ściśle określonych formuł słownych, których rolą było wzmacnianie mocy przeprowadzanych równolegle rytuałów. W społeczeństwach pierwotnych istniała silnie zakorzeniona wiara w moc sprawczą wypowiadanych z określoną intencją słów. Wówczas też zostały sformalizowane elementy magicznych działań. Formuły słowne musiały być wypowiadane $\mathrm{w}$ dosłownym brzmieniu, przez specjalnie wyznaczonego do tego celu człowieka, w konkretnym miejscu i czasie. Wypełnienie tych wszystkich warunków determinowało powodzenie całego przedsięwzięcia oraz wpływało na skuteczność praktyk magicznych ${ }^{24}$. Formuly, które były wówczas wypowiadane podczas czynności zrywania ziół, miały na celu wzmocnienie właściwości leczniczych roślin. Magiczna formuła przechowała się u Pliniusza, aby odniosła oczekiwany skutek, należało ją trzykrotnie powtórzyć. Syreniusz pisał o niej krytycznie, choć nie omieszkał jej zacytować. Twierdził, że zioła mają moc nadaną im przez Boga i w związku z tym nie ma potrzeby wzmacniać ich sił leczniczych przez wypowiadanie „nikczemnych słów”. Jego zastrzeżenia dotyczyły również tego, że wspomniana przez Pliniusza formuła miała swoje źródło w pogaństwie, a zatem kłóciła się z ideologią religijną Syreniusza ${ }^{25}$. Tymczasem tradycja chrześcijańska wprowadziła własne zaklęcia, mające formę modlitw, w których proszono Boga i świętych o pomoc. Słowne formuły były kierowane również do chorych, którym życzono powrotu do zdrowia. Trzeci rodzaj to zaklinanie, czyli regułki, którymi przemawiano do samej choroby lub do sily nieczystej odpowiedzialnej za powstanie dolegliwości ${ }^{26}$. W epoce nowożytnej nadal popularny był pogląd, który wiąże się z postaciami Orygenesa oraz św. Augustyna, zakładający, że przyczyny opanowania organizmu ludzkiego przez chorobę należy upatrywać w szkodliwym działaniu sił lub bytów nadprzyrodzonych. Wierzono niekiedy również w to, że te byty same w sobie są chorobą.

24 A. Kuchta, Zaklęcia, tabu i zaklinania - w jaki sposób język tworzy świat? Rola magii jezzykowej w spotecznościach pierwotnych, „Maska. Magazyn antropologiczno-społeczno-kulturowy” 2017, nr 33, s. 117-121.

25 Sz. Syreniusz, op. cit., ks. I, rozdz. 34, k. 128. Treść formuły: „Reseda morbos, Reseda, scisne, scisne, quis hic pullos egerit, nec pedes, nec caput habeant".

26 R. Kieckhefer, Magia w średniowieczu, tłum. I. Kania, Kraków 2000, s. 111. 
Z czynnością zbierania ziół wiązało się zalecenie odnoszące się do miejsca, z którego należało pozyskiwać materiał zielarski, a także czasu, który powinien być ściśle przestrzegany, aby zioła mogły być skuteczne w działaniu. W medycynie ludowej obowiązywała zasada zbierania roślin leczniczych przed wschodem słońca, ale po północy ${ }^{27}$. Wymóg ten nie dotyczył przekonania o lepszych właściwościach materiału zielarskiego, ale był bezpośrednio związany z praktykami, których wypełnienie miało gwarantować postępowanie zgodne z zasadami sztuki zielarskiej. Źródła europejskie podawały również informacje, że zbieranie ziół powinno się odbywać boso, w milczeniu, bez użycia narzędzi żelaznych ${ }^{28}$.

Istniało przeświadczenie, że na skuteczność oddziaływania poszczególnych ziół o właściwościach nadprzyrodzonych miał wpływ czas ich zbierania oraz forma użycia, dlatego ważne było zbieranie ziół w konkretnym terminie. W zielnikach podnoszono znaczenie ciał niebieskich dla skuteczności działania poszczególnych ziół, dlatego starano się ściśle przestrzegać pór dnia, nocy oraz roku podczas czynności zrywania lub wykopywania ziół leczniczych. Autorzy herbarzy renesansowych zalecali pozyskiwanie ziół w konkretnych porach roku, twierdząc, że na koncentrację ich właściwości leczniczych wpływają poszczególne znaki zodiaku. Syreniusz kazał kopać korzeń dzięgielnicy (łac. Angelica magna), która miała posiadać działanie ochronne przeciw czarom oraz chronić od niekorzystnego wpływu planet, gdy Księżyc lub Merkury wejdą do znaku Strzelca albo Bliźnią ${ }^{29}$. Należało zdaniem Syreniusza brać pod uwagę układ gwiazd podczas wykopywania korzenia ziela o nazwie miarz lub mistrzownik (łac. Imperatoria ostrutium). Trzeba było także - uwzględniając fazy Księżyca - pokroić następnie ów korzeń na plastry oraz umocować na czole w ten sposób, aby nie spadły. Dopiero wykonanie wszystkich tych zaleceń miało gwarantować skuteczne działanie tego zioła przeciw wszom żerującym na ciele człowieka ${ }^{30}$. Kopr górny (skalny, łac. Libanotis montana), wykopywany w okresie działa-

27 M. Czerwiński, Magia, mit, fikcja, Warszawa 1975, s. 29; K. Górny, Czas i przestrzeń $w$ magii leczniczej, „Literatura Ludowa” 1996, nr 40, passim.

28 R. Kieckhefer, op. cit., s. 108-109.

29 Sz. Syreniusz, op. cit., ks. I, rozdz. 26, k. 105, 106.

30 Ibidem, ks. I, rozdz. 32, k. 123. 
nia pewnych aspektów, miał być lekiem poprawiającym płodność. Kiedy jednak był wyrywany podczas innych aspektów i podczas innego układu gwiazd, odwrotnie - czynił ludzi bezpłodnymi ${ }^{31}$. W zielnikach znalazły się informacje o kilku ziołach, które miały być skuteczne przeciw czarom - pod warunkiem że zostaną zebrane przed wschodem słońca i zostaną zjedzone w stanie surowym ${ }^{32}$. Niekiedy kierowano się kalendarzem kościelnym, przykładając szczególną wagę do letniego zrównania dnia z nocą. Dlatego bylicę należało zrywać w wigilię św. Jana ${ }^{33}$. Podobnie, w tym samym terminie, radzono zbierać ziele dziurawca, zwane również zielem świętojańskim, podczas kwitnienia przypadającego właśnie na słowiańskie święto sobótki. Wykonanie określonych rytuałów było zatem konieczne, aby w pełni wykorzystać moc, jaką mogły dać zioła. Widać też na tych przykładach, jak magia ziołolecznicza spajała się z religią chrześcijańską.

Praktyki magiczne obejmowały również sposób pozyskiwania rośliny lub jej części. W zależności od tego, jakie gesty wykonywała zielarka podczas zbierania materiału zielarskiego, takiego efektu leczniczego należało się spodziewać. Jako przykład może tutaj posłużyć kora bzu (łac. Sambucus nigra). Kierunek jej zeskrobywania miał decydować o tym, czy późniejsze spożycie tego medykamentu wywoła wymioty, przeczyszczenie czy jedno i drugie równocześnie ${ }^{34}$. Podobnie miały działać nasiona skoczka mniejszego (łac. Lathyris titymalis). W zależności od tego, czy chciano uzyskać efekt przeczyszczenia, czy wymiotów, w taki sposób zrywano tę roślinę - od góry do dołu lub odwrotnie ${ }^{35}$. Liczyły się też dodatki do leków ziołowych. Mleczko pozyskiwane ze skoczka, ziela zwanego również czartowym lub wilczym mlekiem (łac. Tithymalus), połączone $\mathrm{z}$ octem winnym i woda miało właściwości przeczyszczające, to samo ziele z dodatkiem wody z rozmąconym miodem powodowało natomiast torsje ${ }^{36}$.

31 Ibidem, ks. II, rozdz. 10, k. 403.

32 J. K. Haur, op. cit., k. 455. Haur radził też, aby zbierać zioła podczas ciepłego i słonecznego dnia.

33 Marcin z Urzędowa, op. cit., cap. XXXIIII, k. 31-32.

34 Sz. Syreniusz, op. cit., ks. V, rozdz. 192, k. 1506. Syreniusz powtarzał takie informacje za Pliniuszem.

35 Marcin z Urzędowa, op. cit., cap. CCIX, k. 183.

36 Ibidem, cap. LXXXVI, k. 77. 
W świetle tych przekazów widać, że celem, który przyświecał autorom zielników - obok przekazania rzetelnej z ich punktu widzenia wiedzy leczniczej - było uświadomienie, że na pomyślny skutek procesu leczenia składają się rytuały, gesty i odpowiednie formuły słowne, co wiązało się nieodłącznie z posiadaniem pogłębionej wiedzy nie tylko na temat właściwości leczniczych konkretnych ziół, ale i praktyk magicznych. Autorzy herbarzy dawali tym samym do zrozumienia, że z leczeniem łączy się duża odpowiedzialność, jak również to, że sztuka ta jest znana jedynie garstce wyspecjalizowanych osób.

Przywiązywano dużą wagę do dawek. Zmiana dawkowania pociągała bowiem za sobą konsekwencje w postaci całkowicie odwrotnego procesu leczenia. Dla przykładu wypicie jednego kieliszka wina z moczonym w nim korzeniem kopru górnego (łac. Foeniculum montanum) przez kobietę „przed społecznym złączeniem małżeńskim” miało skutkować zatrzymaniem nasienia i tym samym wspomagać zajście w ciążę. Natomiast już wypicie drugiego kieliszka powodowało skutek zgoła odwrotny ${ }^{37}$.

\section{Ochrona przed siłami nieczystymi}

Analizując przepisy w zielnikach, można łatwo zauważyć, że wśród ludzi żyjących w XVI w. obecny był strach przed szatanem i diabelskimi siłami, które miały stale zagrażać człowiekowi ${ }^{38}$. Zalecenia zawarte $\mathrm{w}$ herbarzach miały na celu ukojenie tego lęku przez podanie odpowiedniego antidotum. Zwróciłam uwagę na to, że w zielnikach znalazło się sporo przepisów służących ochronie przed siłami nieczystymi i czarną magią. Rytuały zabezpieczające przed czarami i urokami były podejmowane, aby przeciwdziałać tym zjawiskom, w których istnienie silnie wierzono. Z drugiej natomiast strony znalazły się rady, jak pomagać w sytuacji, kiedy już doszło do rzucenia czarów czy klątwy na konkretne osoby lub za sprawą diabła.

37 Sz. Syreniusz, op. cit., ks. II, rozdz. 10, k. 403.

38 Por. B. Baranowski, O hultajach, wiedżmach i wszetecznicach. Szkice z obyczajów XVII i XVIII w., Łódź 1988, s. 90-91; M. Rudwin, Diabet w legendzie i literaturze, tłum. J. Illg, Kraków 1999, s. 5-6 i nast.; J. Wijaczka, Magia i czary. Polowanie na czarownice i czarowników w Prusach Książęcych w czasach nowożytnych, Toruń 2008, s. 40. 
Próbowano chronić się przed czarami na różnorakie sposoby. Sadzono wokół domu odpowiednie rośliny, które miały - jak wierzono - właściwości ochronne i nie dopuszczały sił nieczystych do domu. W zielnikach znalazły się zalecenia, jakie rośliny należy sadzić, aby chronić domostwo i domowników przed czarami oraz siłami nieczystymi. Do takich roślin autorzy renesansowych herbarzy zaliczyli bukwicę (łac. Betonica officinalis) oraz gdułę, ziele noszące również nazwę wieprzowy chleb (łac. Cyclamen europaeum). „W którym domie bukwica bądź sama przez się, bądź sadzona roście, tam czary i gusła żadne nie mogą szkodzić”, twierdził Syreniusz za Pliniuszem $^{39}$. Marcin z Urzędowa, też za Pliniuszem, dowodził, że gdułę „dobrze siać przy domach, abowiem, gdzie je sieją, powiada, nie zaszkadzają czary żadne" 40 .

Innym sposobem było umieszczanie konkretnych ziół w domach i budynkach gospodarczych. Aby oddalić czary, które mogłyby zagrozić mieszkańcom domu, autorzy herbarzy kazali wieszać wiązki suszonych ziół nad drzwiami wejściowymi oraz w otworach okiennych. Bylica chroniła od czarów oraz wypędzała siły nieczyste, które zdążyły już zadomowić się w przestrzeni domu. Należało ją powiesić w domu nad drzwiami i oknami, najlepiej w wigilię św. Jana ${ }^{41}$. Podobne właściwości ochronne miała posiadać cebula zamorska (łac. Scilla maritima), która „we wrociech abo we drzwiach zawieszona, broni wszelakim czarom w domu szkodzić” ${ }^{42}$. Syreniusz pisał też o roślinie o nazwie sadliczka, mającej ochraniać domostwa, ludzi oraz zwierzęta. Wystarczyło zawiesić ją na framudze drzwi ${ }^{43}$. Takie

39 Sz. Syreniusz, op. cit., ks. V, rozdz. 1, k. 1250.

40 Marcin z Urzędowa, op. cit., cap. CXXX, k. 113. Podobnie powoływał się na Pliniusza Syreniusz, pisząc, że tam, gdzie rosła gduła, „tam żadne czary szkodzić nie mogą”; Sz. Syreniusz, op. cit., ks. II, rozdz. 93, k. 623.

41 Marcin z Urzędowa, op. cit., cap. XXXIIII, k. 31-32. Marcin z Urzędowa wiedział, że jest to zwyczaj, który opisywał już Pliniusz: „[...] iż gdy będzie wisiała nad wroty, drzwiami, fortkami, okny, tedy onemu domu czary nic nie uczynią, ani człowiekowi żadnemu zaszkodzenia, który nosi z sobą"; Sz. Syreniusz, op. cit., ks. III, rozdz. 48, k. 725.

42 Sz. Syreniusz, op. cit., ks. III, rozdz. 131, k. 866. Marcin z Urzędowa, powołując się na Dioskurydesa, Pliniusza i Pitagorasa, pisał: "Jest silne lekarstwo przeciw czarom, na drzwiach zawiesiwszy, albo wrotach, w takim domu czary nie uczynią zaszkodzenia”. Marcin z Urzędowa, op. cit., cap. CCCXXVII, k. 280.

43 Sz. Syreniusz, op. cit., ks. II, rozdz. 53, k. 558. 
samo działanie przypisywano agrestowi (łac. Ribes uva-crispa), którego gałązki wystawione w oknach i drzwiach miały „czary, gusła w domu nie dopuszczać" ${ }^{4}$.

Autorzy zielników proponowali również zrywanie bądź dotykanie roślin, trzymanie ich w rękach albo przykładanie choremu. Popularnością cieszyło się doczepianie ziół do różnych części ciała oraz noszenie ich ze sobą w kształcie amuletu zawieszonego na szyi, pierścienia lub wieńca zakładanego na głowę. Niekiedy nakazywano nosić takie zioła w butach. Często brakuje szczegółowych informacji o tym, gdzie konkretnie człowiek miał nosić ziele, aby chroniło go przed czarami i zabezpieczało przed rzuceniem uroków. Wydaje się, sądząc po ilości przekazów źródłowych, że przywiązywano dużą wagę do tego, aby zioła, którym przypisywano moc magiczną, znajdowały się $\mathrm{w}$ bezpośrednim kontakcie $\mathrm{z}$ człowiekiem zagrożonym siłami nieczystymi. Dla Syreniusza sposobem na to, aby uchronić się przed wpływami szatana, było umieszczanie blisko przy ciele ziela dziurawca, zwanego też dzwonkami panny Marii (łac. Hypericum perforata) ${ }^{45}$. Dzięgiel (łac. Angelica sylvestris et archangelica), noszony przy sobie, miał strzec nie tylko człowieka, ale również dom, w którym przebywali domownicy ${ }^{46}$. Podobne właściwości rozciągano na orlik (łac. Aquilegia vulgaris) ${ }^{47}$. Kolejna roślina, która miała chronić człowieka przed diabelskim wpływem, to ziele o nazwie mikołajek (łac. Eryngium campestre). Tej roślinie przydawano rozległe właściwości, potwierdzone przez wielu autorów zielników. Właściwości tego ziela zmieniały się w zależności od metody jego używania. W przypadku stosowania przeciw czarom zakładano wieszanie go na szyi lub noszenie bezpośrednio przy sobie - wierząc, że „czary i czartowskie sprawy temu szkodzić nie mogą, ktoby go przy sobie nosił abo na szyi miał”48. Podobnie od czarów oraz uroków miały chronić zawieszone na szyi główki wyżliny z nasieniem (łac. Anthirrinum) ${ }^{49}$, a także korzeń archanieliki (łac. Archan-

44 Marcin z Urzędowa, op. cit., cap. C, k. 392.

45 Sz. Syreniusz, op. cit., ks. III, rozdz. 111, k. 828.

46 Ibidem, ks. I, rozdz. 22, k. 91.

47 Ibidem, ks. III, rozdz. 148, k. 903.

48 Ibidem, ks. III, rozdz. 22, k. 681. Dla mikołajka znajdowano szersze zastosowanie - afrodyzjaka, rośliny odtruwającej, a także pozwalającej pijącemu zachować trzeźwość.

49 Ibidem, ks. II, rozdz. 73, k. 593. 
gelica littoralis $)^{50}$. Bylica, „kto ją nosi przy sobie, nie trzeba mu się bać czarów, ani żadnych zabobonów, ani złych bestii jadowitych”, twierdził Marcin z Urzędowa za Pliniuszem ${ }^{51}$. Kiedy już doszło do rzucenia czarów, także miała pomagać bylica, którą Syreniusz kazał powiesić na szyi ${ }^{52}$. Również rosiczki (łac. Drosera rotundifolia) używano w celu uleczenia opętanych przez diabła. W tym przypadku też należało nosić zioło bezpośrednio na ciele, najlepiej na szyi w formie zawieszki. Syreniusz twierdził, że rosiczka „szatany w opętanych ucisza" ${ }^{3}$. Pomocne było w walce z nawiedzonymi przez duchy ziele Matki Bożej włoski (łac. Adiantum), które „duchy w ciele poleruje, i wolne a swobodne czyni" 54 .

Obok tych sposobów istniały też inne praktyki, których celem było wykorzystanie roślin jako środków magicznych. Używano ziół również w formie okadzania. Okadzanie przestrzeni domu bylicą miało chronić domostwo przed siłami nieczystymi i przed czartem. Starano się niekiedy łączyć tradycję pogańską z religią chrześcijańską. Pojawiały się zapiski, że bylica powinna być uprzednio święcona, dopiero wówczas będzie skuteczna jako remedium przed czarami, gdyż „oddala diabelstwo, gdy będziesz nią kadził w domu"55. Podobnie miało działać podkurzanie liśćmi dębu. Zdaniem Krescencjusza diabeł bał się, uciekał przed tym zapachem, gdyż drażnił go dym z dębowych liści ${ }^{56}$. W tym samym celu - aby odpędzić „czary szatańskie” - okadzano wnętrze domu kokornakiem. „Gdy zakadzisz tym zielem [...] diabelstwo z domu wypądza”. Diabeł i wszystkie siły nieczyste opuszczały przestrzeń, gdyż nie były w stanie zaakceptować tej woni ${ }^{57}$. Do okadzania używano również korzenia piwonii. Miał on wypędzać czarty,

50 Ibidem, ks. I, rozdz. 23, k. 99.

51 Marcin z Urzędowa, op. cit., cap. XXXIIII, k. 33.

52 Sz. Syreniusz, op. cit., ks. III, rozdz. 48, k. 725.

53 Ibidem, ks. I, rozdz. 100, k. 331.

54 Ibidem, ks. II, rozdz. 69, k. 587.

55 H. Spiczyński, op. cit., cap. $1 \mathrm{I}$, list $1 \mathrm{v}$.

56 „Powiadają też, iż dymu jego liścia czarth się boi”; P. Crescentyn, op. cit., ks. VI, k. 463.

57 H. Spiczyński, op. cit., cap. 13 M, list 9; Sz. Syreniusz, op. cit., ks. III, rozdz. 4, k. 649. 
złe duchy oraz udręczone dusze ${ }^{58}$. Przeciw czarom, gusłom i „nagrawaniu szatańskiemu" miało służyć noszenie przy sobie lub okadzanie domu zielem dziurawca (łac. Hypericum perforata). Skuteczność użycia tej właśnie rośliny potwierdzać miała nazwa, gdyż po łacinie ziele to było nazywane Fuga Daemonum ${ }^{59}$.

\section{Czynności magiczne w celu zniwelowania lęku}

Stosując praktyki magiczne, próbowano niwelować niekorzystne stany psychiczne i lęki związane z przekonaniem o istnieniu oraz bytowaniu sił nadprzyrodzonych, których celem było szkodzenie człowiekowi. W kilku miejscach pojawiły się rady, w jaki sposób ustrzec się lęku przed ciemnością i strachu przed koszmarami sennymi. Obecność tego rodzaju informacji dowodzi, że był to problem psychiczny, z którym zmagała się część ludzi. Autorzy zielników rozumieli, że niektórzy odczuwali nieracjonalny strach przed tym, że ktoś rzuci na nich urok, ktoś zaczaruje. W związku z tym w takich wypadkach szukali odpowiedniego remedium. Spiczyński zalecał osobom obawiającym się, że ktoś rzuci na nich czar, picie wódki z dziewanny. Taka wódka miała również chronić ulubione miejsce w domu w ten sposób, że należało nią pokropić przestrzeń domu, w której najczęściej się przebywało $^{60}$. Obok wymienionych już metod i praktyk, mających na celu uleczenie osoby zaczarowanej, stosowano wiele innych. $Z$ tradycji greckiej pochodzi sposób przewiązywania się zielem bylicy, aby zapobiec ewentualnemu rzuceniu czarów na kobietę ${ }^{61}$. Ziele o nazwie rączki, albo inaczej dłoń chrystusowa (łac. Orchis conopsea), noszone przy sobie, miało chronić przed zadawanymi truciznami oraz przed czarami, które były rzucane przez baby ${ }^{62}$. Widać zatem, że w zielnikach znalazły się przepisy na magię

58 M. Siennik, op. cit., ks. I, cz. I, rozdz. 161, k. 120. „Duchy złe i nieczyste z ludzi i utrapienia od nich i wolne czyni korzeń używany i tymże je podkurzając”; Sz. Syreniusz, op. cit., ks. III, rozdz. 92, k. 787.

59 Sz. Syreniusz, op. cit., ks. III, rozdz. 111, k. 828.

60 H. Spiczyński, op. cit., O wódkach ziót rozmaitych, p. 100v.

61 Marcin z Urzędowa, op. cit., cap. XXXIIII, k. 31.

62 H. Spiczyński, op. cit., cap. 213 H, list 81; Sz. Syreniusz, ks. III, rozdz. 73, k. 765. 
ochronną. Marcin z Urzędowa za Pliniuszem podał pewny sposób, w jaki można ustrzec się czarów: „[...] gdy kto puszczając urynę, po niey zawżdy plunie; także plunąć w bok prawy, pierwey niźli człowiek obuje; także plunąć, gdy kto jakie złe miejsce przestąpi"63.

Rośliny miały często wyspecjalizowaną moc, niektóre np. chroniły wyłącznie dzieci przed czarami, gusłami oraz zabezpieczały przed strachem, który mógł być następstwem przebywania w ciemności lub efektem koszmarów sennych. Takie właściwości przypisywano piwonii ${ }^{64}$. Zakładano, że podobnie będzie działała jemioła włożona małym dzieciom bezpośrednio do kolebki - miała powodować, że „przestrachy nie przychodziły i straszliwe widzenia" ${ }^{65}$. Przed urzeczeniem i lękiem powinno chronić ziele dziewięćsił (łac. Carlina acaulis), którym miano okładać dziecko w kolebce $^{66}$. „Od złego urzecenia bab i od innych strachów” miały chronić kosatki (łac. Sparganium) ${ }^{67}$. Specjalnie do ochrony dzieci przed zaczarowaniem, lękami i koszmarami sennymi używano także rośliny pochodzenia obcego o nazwie postawne ziele (łac. Melanospermum peloponesiacum) ${ }^{68}$. Bardziej znany był kopr ogrodny (łac. Anethum graveolens), którego sokiem smarowano skronie dzieci, aby je zabezpieczyć przed nocnicami, czyli przed zmorami sennymi, które często łączyły się z dolegliwościami psychosomatycznymi, wrażeniem duszenia i złudzeniami optycznymi ${ }^{69}$. Co gorsza, Marcin z Urzędowa i Syreniusz zalecali okadzać dzieci wrotyczem (łac. Tanacetum vulgare), aby poprawić im nastrój, co mogło być skuteczne, ale uzależniające, a przy przedawkowaniu powodowało halucynacje $\mathrm{e}^{70}$.

63 Marcin z Urzędowa, op. cit., ks. II, cz. 3, cap. XXXI, k. 454.

64 Sz. Syreniusz, op. cit., ks. III, rozdz. 92, k. 787.

65 H. Spiczyński, op. cit., cap. 259 E, list 96.

66 Ibidem, cap. $100 \mathrm{~B}$, list 41v.

${ }^{67}$ M. Siennik, op. cit., ks. I, cz. I, rozdz. 100, list 78. Inna nazwa tego ziela to wilcze bobki. Sz. Syreniusz, op. cit., ks. V, rozdz. 25, k. 1288.

68 Sz. Syreniusz, op. cit., ks. I, rozdz. 41, k. 144, 145.

69 Ibidem, ks. II, rozdz. 13, k. 427.

70 Marcin z Urzędowa, p. 297; Sz. Syreniusz, op. cit., ks. III, rozdz. 99, k. 812. Jak wykazały obecne badania, zawarty we wrotyczu tujon ma właściwości porównywalne do działania kanabinoli; por. ustalenia Henryka Różańskiego - http://www.rozanski.ch/tanacetum.html (dostęp: 12.01.2020). 
Istniało przekonanie na temat wyjątkowych właściwości zapachów i odwoływano się do tych właściwości roślin, chcąc uleczyć różnego rodzaju przypadłości ciała. Woń wydzielana przez niektóre rośliny, np. anyż, miała odpędzać niedobre sny. Wystarczyło włożyć anyż do sakiewki i powiesić blisko nosa, aby osoba śpiąca mogła stale wdychać zapach tej rośliny ${ }^{71}$. Za pomocą zapachów ziołowych próbowano również chronić się przed morowym powietrzem i zapobiegać w ten sposób wybuchowi epidemii. Jako przykład można podać kopr górny (łac. Libanotis montana), który wystarczyło powiesić na szyi ${ }^{72}$. Posługując się wonią konkretnych ziół, próbowano odstraszyć owady albo jadowite węże $\mathrm{e}^{73}$.

W innych miejscach autorzy zielników opisywali zioła i metody, które miały sprawić, że w cudowny sposób człowiek będzie osiągać pożądany efekt zdrowotny - kobiety niepłodne powinny zachodzić w ciążę, te, które były w niechcianej ciąży, miały ronić płód, położnice rodzić bez problemu, chory zdrowieć, dzieci spokojnie zasypiać, ból ustępować, wrzody goić się, krwotok tamował się w sposób niemal samoistny, ludzie zyskiwali przychylność otoczenia, gady i płazy uciekały przed człowiekiem i następowały tym podobne zdarzenia, dzięki zastosowaniu uświęconych tradycją przepisów z zielników.

Syreniusz podawał nawet przepis chroniący przed nagłą i niespodziewaną śmiercią. Co ciekawe, można było tego dokonać, używając zioła obcego pochodzenia przywożonego z Nowego Świata. W ten sposób pojawiły się przepisy z zupełnie innego kręg kulturowego, które poświadczają przepływ wiedzy między kontynentami ${ }^{74}$.

71 Sz. Syreniusz, op. cit., ks. II, rozdz. 11, k. 408.

72 Ibidem, ks. II, rozdz. 10, k. 403.

73 Zob. informacje na temat dymu oraz soku np. z ruty, macierzanki czy piołunu; P. Crescentyn, op. cit., k. 254; Sz. Syreniusz, op. cit., ks. II, rozdz. 40, k. 509; ibidem, ks. II, rozdz. 1, k. 357.

74 Próbowano wykorzystać właściwości słonecznika peruwiańskiego (łac. Helianthus annuus). Autor zielnika twierdził, że noszenie go na szyi pomoże w zachowaniu dobrego zdrowia i życia; Sz. Syreniusz, op. cit., przydatek do ks. V, rozdz. 209, k. 1528. 


\section{Zjawisko magii miłosnej}

Popularnością cieszyła się magia miłosna. Jej celem było zdobycie wybranka lub wybranki serca albo przeciwnie - chęć doprowadzenia do oziębienia relacji, ingerowanie $\mathrm{w}$ sferę płodności, wywołanie impotencji. Syreniusz twierdził, że ziele zerwy (łac. Campanula persicifolia) wyczaruje miłość, gdyż „starzy na czary pospolicie do miłości używali tego ziela i sposób do używania tego wiedzieli"75. Wierzono, że zioła mogą wpływać na ludzkie emocje. Skorzonera (łac. Scorsonera hispanica et humilis) sprawiała, że człowiek przestawał tęsknić za ukochanym. Zioło to odpędzało „czary, przez które tęskność abo od rozumu odeszcie bywa przez złego człowieka uczynione. Abo komuby dla miłości był czarowany trunek do picia dany"76. Tym, na których rzucony został czar miłości, miała pomagać werbena (łac. Verbena officinalis) ${ }^{77}$. Zerwany dziewięciornik (przywrot, łac. Parnassia palustris) miał z kolei przywracać uczucie między mężem a żoną ${ }^{78}$.

Do praktyk magicznych można również zaliczyć kąpiele ziołowe. Marcin Siennik wspomniał o czarach rzucanych na dziewczyny w celu przywiedzenia ich do utraty dziewictwa. Odczynić takie czary można było przez omycie ciała dziewki w wywarze z wrotyczu ${ }^{79}$. Także Spiczyński polecał kąpiele we wrotyczu młodym niewiastom, co do których zachodziło podejrzenie, że zostały zaczarowane. Efektem takiej metody miało być odczarowanie. Tym samym kąpiel również należała do magicznych rytuałów, sprawiających, że „odejdą [...] czary” ${ }^{80}$. Czasami mycie całego ciała w naparze z konkretnego zioła miało wspomagać działanie innego rodzaju. W przypadku bożego drzewka ziele to dodatkowo można było moczyć w piwie i pić oraz nosić przy sobie, jeśli zachodziło domniemanie, że zostały

75 Ibidem, ks. V, rozdz. 31, k. 1300.

76 Ibidem, ks. IV, rozdz. 140, k. 1241.

77 Ibidem, ks. III, rozdz. 125, k. 850.

78 Marcin z Urzędowa, p. 136.

79 M. Siennik, op. cit., ks. I, cz. I, rozdz. 247, list 179: „Gdyby dziewkę sczarowano, chcąc ją na nierząd tym przywieść, gdy się ona w tej wrotyczy omyje, czary ją opuszczą”.

${ }^{80}$ H. Spiczyński, op. cit., cap. 247 B, list 92: „[...] iżby z gorącej miłości wszczął się jej niepokój, a iżby rozumiała, żeby była dziewka, a iżeby panieństwo miała stracić, tedy się w tej wrotyczy niechaj umyje, odejdą od niej ty czary". 
rzucone czary na małżeństwo. Tam, „gdzieby stadło uczarowane było, iżby jedno ku drugiemu chuci ani woley nie miało”, wówczas należy zastosować rytuały, które odwrócą szkodliwe działanie magii ${ }^{81}$. Praktykowanie magii można odnotować także na podstawie przekazu zawartego we włoskiej rozprawie Tajemnice... Aleksego z Piemontu. Najpewniej autor miał na myśli magię miłosną, której celem było wywołanie u mężczyzny określonego efektu uczuciowego. Metody, które proponował, były zgoła oryginalne:

Przeciw czaram sprośnych niewiast któremi dla psoty mężczyzny mamią. Aby zaś mógł odczynić, jeśli baczysz, która to sprawiła, przyłóż pilności, abyś jej łajna dostał. Włóż go sczarowanemu po ranu w prawy bok, a wnet go czary opuszczą, skoro smród poczuje. Albo w piórko nabierz trtęci, a zatkawszy włoż sczarowanemu pod głowną poduszkę albo pod próg, gdzie przychodzi, bo skoro przestąpi, opuszczą go czary.

Albo niechaj sczarowany pomarze wszystko ciało sobie olejem z olejnice, wmieszawszy weń żołć krukową, a będzie wolen od czarów. Albo go podkurz zębem człowieka umarłego, a opuszczą go czary. Mąż, który $\mathrm{z}$ sobą nosi serce wrony samca, a niewiasta samice, snadnie się zejdą ${ }^{82}$.

Białogłowy „do czarów miłością nierządną zwyciężenia” używały ziela o nazwie kotczy pazur albo miłosna (łac. Reseda luteola), które służyło do „nierządnych a nieprzystojnych spraw” ${ }^{3}$. W ramach magii miłosnej próbowano ustalić uczucia względem drugiej osoby. Jednym ze sposobów było przyłożenie do ciała liścia pacierzyczki, rośliny obcego pochodzenia, nierosnącej w Polsce, a następnie obserwowanie reakcji skóry w kontakcie z liściem i śliną, za pomocą której przytwierdzano liść do ciała. Lekkie zaczerwienienie naskórka było oznaką miłości, pojawienie się zmian skórnych

81 Lekarstwa doświadczone, które zebrat uczony lekarz pana Jana Pileckiego, któremu sa. przydane lekarstwa końskie z cwiczeniem tego lekarza. Przydaliśmy y figury ziot rozmaitych ku lekarstwu z ziotkami dostatecznemi sprawione, teraz znowu na światto wydane, Kraków 1564, Nauka leczenia trucizny i jadu rozmaitego, p. 157v; zob. także: Sz. Syreniusz, op. cit., ks. II, rozdz. 4, k. 370.

${ }^{82}$ Aleksego Pedemontana Ksieggi siedmioro Taiemnic rozmaite nauki w sobie maiace z tacińskiego na polski język teraz nowo przetożone przez Marcina Siennika, ks. 5, rozdz. 3: O leczeniu wstydu, w: M. Siennik, op. cit., list 554.

83 Sz. Syreniusz, op. cit., ks. I, rozdz. 33, k. 124. 
miało być natomiast równoznaczne $\mathrm{z}$ negatywnym nastawieniem ${ }^{84}$. Widać na podstawie tych przykładów, że czasami mieliśmy do czynienia z magią pomocniczą, która stawiała sobie za cel udzielenie pomocy osobom w sferze uczuciowej. Niekiedy jednak rytuały te miały w sposób świadomy szkodzićs ${ }^{85}$.

\section{Praktyki magiczne w celu polepszenia płodności}

W społeczeństwie staropolskim ogromną wagę przywiązywano do płodności, starając się wypełnić nakazany wzorcami kulturowymi obowiązek posiadania dzieci. Tym chyba należy tłumaczyć sporą liczbę przepisów i zaleceń ukierunkowanych na pomoc w doczekaniu się potomstwa. Istniało przekonanie, że bezpłodność, problemy w relacjach między małżonkami oraz w ich życiu intymnym mogły być następstwem czarów. W przypadku małżonków, na których zostały rzucone czary, pomocą miało służyć zioło o nazwie zapaliczka, nierosnące na ziemiach polskich (łac. Ferula communis et ferulago). Osoba odpowiedzialna za zdejmowanie czarów wieszała młode naziemne części tej rośliny po trzy sztuki na szyi każdego z małżonków, li-

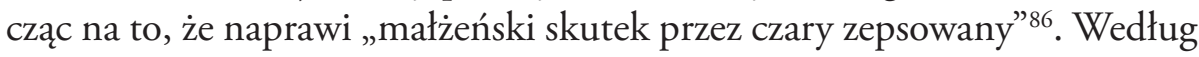
Siennika miały też pomagać praktyki polegające na mazaniu ścian domu krwią czarnego psa, kadzeniu przestrzeni domu palonym zębem trupa, a także spożywanie mięsa $\mathrm{z}$ dzięcioła ${ }^{87}$.

W zielnikach zostało zamieszczonych wiele przepisów służących polepszeniu życia erotycznego małżonków. Praktyki magiczne polegały na wkładaniu konkretnego zioła do łoża, noszeniu go ze sobą, piciu naparów lub kąpaniu się w wodzie zawierającej ziołowe ingredienty. Takie wszechstronne zastosowanie miało boże drzewko (łac. Abrotanum mas), opisywane w kilku zielnikach jako zioło o mocy czarodziejskiej ${ }^{88}$. Małżonkowie chronili się przed czarami, kładąc to ziele do swojego łoża. Zioło to według

\footnotetext{
84 Ibidem, ks. V, rozdz. 213, k. 1531.

85 Por. R. Kieckhefer, op. cit., s. 127-131.

86 Sz. Syreniusz, op. cit., ks. I, rozdz. 53, k. 181.

87 M. Siennik, op. cit., ks. V, O lekarstwach wnątrza, list 378.

88 Sz. Syreniusz, op. cit., ks. II, rozdz. 5, k. 370; J. K. Haur, op. cit., k. 455.
} 
opinii Syreniusza powinno działać dodatkowo jako afrodyzjak ${ }^{89}$. Jeszcze inny sposób miały włoskie kobiety, które suszyły, a następnie ścierały na proch łąkowe storczyki (łac. Orchis), zwane też w polskim ludowym nazewnictwie lisimi jajkami, po czym mieszały je z kozim mlekiem i dawały do spożycia swoim mężom, dla „pobudzenia chciwości cielesnej”. Zdaniem Syreniusza zioło to było przeznaczone dla mężów, którzy „w małżeństwie będący do skutku małżeńskiego gnuśni i niepotężni”. Chociaż autor podawał, że lisie jajka również używają „i wszetecznicy, i żądze cielesnej pełni, a niepowściągliwi" 90 . Smarowanie męskich i żeńskich narządów intymnych zielem złocienia, zwanym również kozimi jajkami (łac. Asphodelus luteus et allus), miało działać niczym afrodyzjak ${ }^{91}$. Jest to jeden $z$ wielu przykładów zastosowania ziół w celu sterowania sferą intymną kobiet i mężczyzn. Można znaleźć również przepisy na używanie ziół mających tłumić popęd płciowy człowieka (antiaphrosidiacum) ${ }^{92}$ oraz receptury na zmniejszenie płodności kobiet. Sprowadzić niepłodność na kobietę można było przez danie jej naparu kwiatu lub nasion wierzby, jak twierdził Piotr Krescencjusz ${ }^{93}$.

Do czarów odwoływały się nie tylko kobiety, ale również mężczyźni. Przez stosowanie praktyk magicznych starano się wpływać na płeć dzieci. Autorzy polskich zielników za Dioskurydesem podawali sposób na płodzenie potomstwa określonej płci. Mężczyzna miał smarować swój członek (membrum virile) lub pić sok z liści rośliny męskiej szczyru (łac. Mercurialis), aby spłodzić syna. Ze spożywania liści szczyru z rośliny żeńskiej miała z kolei rodzić się córka ${ }^{94}$. Inna metoda zakładała jedzenie przez mężczy-

89 Sz. Syreniusz, op. cit., ks. II, rozdz. 5, k. 370.

90 H. Spiczyński, op. cit., cap. 213 C, list 81; zob. także: Marcin z Urzędowa, op. cit., cap. CCLVII, k. 225; Sz. Syreniusz, op. cit., ks. III, rozdz. 5, k. 760.

91 Sz. Syreniusz, op. cit., ks. III, rozdz. 128, k. 861.

92 Syreniusz podawał, że takie właściwości ma ruta; ibidem, ks. II, rozdz. 47, k. 529. Marcin z Urzędowa twierdził, że również ziele kurza noga (łac. Portulaca oleracea); Marcin z Urzędowa, op. cit., ks. I, cap. CCXCIX, k. 255.

93 P. Crescentyn, op. cit., ks. VI, k. 449.

94 H. Spiczyński, op. cit., cap. 139 D, list 55; Sz. Syreniusz, op. cit., ks. III, rozdz. 127, k. 858. Trochę inny przekaz na ten sam temat znalazł się u Marcina z Urzędowa, op. cit., cap. CCXL, k. 212, który kazał wkładać liście tej rośliny do macicy; zob. także: H. Schulz, Zur Wirkung der Mercurialis perennis, L., „Archiv für Experimentelle Pathologie und Pharmakologie" 1886, Bd. 21, H. 1, s. 88-89. 
znę kłączy wspomnianych wyżej lisich jajek, czyli łąkowych storczyków. O tym, jakiej płci dziecko spłodzi, decydowała liczba zjedzonych kłączy lub bulw ${ }^{95}$. Późniejsi autorzy twierdzili, że spożywanie młodego kłącza tej rośliny sprawi, że na świat przyjdzie potomek męski, stare kłącze przyniesie natomiast dziewczynkę. Nieco osobliwy sposób miał polegać na wkładaniu przez kobietę do swojego łona, zaraz po poczęciu, ziela kokornaku z mięsem byka. Działania te miały gwarantować urodzenie dziecka płci męskiej ${ }^{96}$. Widać na tych przykładach, iż ludzie starali się przez tego rodzaju praktyki sterować swoją płodnością i zdobyć wpływ na posiadanie potomstwa o określonej płci ${ }^{97}$.

\section{Czary mające dawać nadludzką siłę, zmieniać osobowość człowieka}

Używano ziół również po to, aby przydać ludziom nadludzkich właściwości i mocy do walki z mitycznymi zwierzętami lub tymi pojawiającymi się w wierzeniach pogańskich. Taką siłę działania przypisywał Spiczyński, ale też Krescencjusz, rucie (łac. Ruta graveolens). Człowiek, który całe ciało obłożył tym zielem, mógł wyruszać na wyprawę mającą na celu zabicie bazyliszka, tj. znanego jedynie z przekazów legendarnych ptaka. Wówczas był pewny, że w żaden sposób nie ucierpi podczas tego nierównego pojedynku. Cechy ochronne tej rośliny polegały na jej specyficznym zapachu, który był w stanie porazić nawet wspomnianego mitycznego ptaka ${ }^{98}$.

Sok z nostrzega (łac. Melilotus officinalis) rozsmarowany na rękach miał sprawiać, że naskórek nie był wrażliwy na wysoką temperaturę i można było chwytać rozżarzone do czerwoności żelazo ${ }^{99}$. Mniejszy zakres działania przypisywano werbenie, zwanej też koszyszczkiem (łac. Verbena officinalis), ale i to zioło miało szerokie zastosowanie w praktykach magicznych. Werbena również charakteryzowała się oddziaływaniem na relacje międzyludzkie. Wystarczyło posmarować się sokiem tego ziela, aby skłonić

95 H. Spiczyński, op. cit., cap. 213 C, list 81.

96 Sz. Syreniusz, op. cit., ks. III, rozdz. 4, k. 650.

97 Por. także: ibidem, ks. III, rozdz. 15, k. 670; ibidem, ks. III, rozdz. 66, k. 757.

98 H. Spiczyński, op. cit., cap. 200 O, list 76; P. Crescentyn, op. cit., k. 254.

99 H. Spiczyński, op. cit., cap. 134 K, list 53. 
drugiego człowieka do przychylności. Noszenie tego ziela ze sobą w ręce lub położenie go pod poduszkę miało z kolei sprowadzać skromność na człowieka, a zatem wpływać na jego osobowość i charakter ${ }^{100}$. Co ciekawe, u Spiczyńskiego znalazła się informacja, że zielem tym leczyli lekarze, wykonując przy tym czynności z pogranicza magii. Według tego przekazu medyk brał w rękę gałązkę tej rośliny w obecności chorego, następnie zadawał pytania cierpiącemu dotyczące jego samopoczucia. Odpowiedź pacjenta była równoznaczna z tym, czy wyzdrowieje, czy umrze. Werbena była również znana w medycynie ludowej w kręgu osób trudniących się zamawianiem choroby i czarami ${ }^{101}$. Syreniusz zaznaczał jednak, że częściej to ziele wykorzystuja „,czarownice do swych gusł i czarów” aniżeli „lekarze do lekarskich potrzeb" 102 .

\section{Czary przeciu zwierzętom}

W zielnikach znalazły się również przepisy mające chronić zwierzęta hodowlane przed czarami. Tych receptur jest znacznie mniej, jednak nie można ich pominą́, gdyż składają się one na obraz kulturowy opisywanego okresu. Niemal wszystkie notatki dotyczące zwierząt odnoszą się do bydła. Czary od bydła miały oddalać dzięgielnica (łac. Angelica magna) ${ }^{103}$, ruta ${ }^{104}$ oraz sadliczka, którą należało uprzednio poświęcić, po czym zawiesić nad wrotami lub bezpośrednio na szyi zwierzęcia, albo po prostu siać w pobliżu obór i chlewów ${ }^{105}$. Pewnym w użyciu zielem powinna być komonica, czyli tzw. czartowe żebro (łac. Scabiosa succisa), którą należało dawać bydłu ugotowaną i wówczas „wszytki czary od bydła giną precz” ${ }^{106}$. Udało mi

100 Marcin z Urzędowa, op. cit., cap. CCCXIII, k. 309.

101 H. Spiczyński, op. cit., cap. 255 E, list 95. Również późniejsi autorzy zielników, jak Syreniusz, zalecali używanie werbeny jako antidotum przeciwko czarom; Sz. Syreniusz, op. cit., ks. III, rozdz. 125, k. 847.

102 Sz. Syreniusz, op. cit., ks. III, rozdz. 125, k. 854.

103 Ibidem, ks. I, rozdz. 26, k. 106.

104 Lekarstwa doświadczone, Nauka leczenia trucizny i jadu rozmaitego, p. 157v.

105 Sz. Syreniusz, op. cit., ks. II, rozdz. 53, k. 558.

106 H. Spiczyński, op. cit., cap. 189, list 72. 
się wynaleźć jedną zapiskę odnoszącą się do konia. Jest to recepta z końca XVII w., zamieszczona w poradniku Haura. Autor zaznaczał wprawdzie, że konie rzadko ulegają czarom, gdyż „czarownice nie końmi do Łysej Góry, ale na ożogach jeżdżą". Jednak jeśli doszło do zaczarowania wierzchowca, wówczas tutaj antidotum było kosztowne dla gospodarza, gdyż przepis zakładał - obok ratowania końskimi odchodami - odymianie konia, który został zauroczony, mirrą, kadzidłem, dodatkowo korą brzozową i białym krowieńcem ${ }^{107}$.

\section{Stosunek autorów zielników do zjauiska czarów}

Ciekawym wątkiem tematycznym jest stosunek autorów zielników do opisywanych przez siebie praktyk magicznych. Syreniusz, który zamieścił najwięcej takich przepisów, powołując się przy tym na autorytety z okresu antycznego i nie tylko, wyraźnie od nich się odciął. „Gusła i zabobony pogańskie” jego zdaniem pochodziły od „Kaldejczyków, Arabów, Medów, Żydów i od lekarzów pogańskich, a Mistrzów wszelakich gusł, czarów, i zabobonów. I teraźniejszych czasów od złych, a Pana Boga się nie bojących chrześcijan”. Tego typu sposobami mieli posługiwać się ludzie z gruntu źli, którzy chcieli szkodzić innym, przy okazji siebie przywodząc do „zatracenia i potępienia wiecznego". Twierdził również, że skuteczność takich praktyk jest znikoma, gdyż „nie z Boga, ani z błogosławieństwa jego świętego pochodzi, ale z gusł od szatana bezecnego" ${ }^{108}$. Z pogardą pisał o „pogaństwie, które się zabobonami bawi”, przeciwstawiając czary sile boskiej ${ }^{109}$. Zwolenników magii nazwał „gusłowiernymi” ${ }^{110}$. Ostatecznie wyrokował, iż „niech kto chce spróbuje. Ja tak wielkiej nie jestem wiary"111. Mimo prezentowania takiego jednoznacznego stanowiska Syreniusz nie omieszkał podawać kolejnych recept i przepisów funkcjonujących wśród prostego ludu. Być może ta asekuracyjna postawa Syreniusza wynikała z tego, że nie chciał on

\footnotetext{
107 J. K. Haur, op. cit., k. 472.

108 Sz. Syreniusz, op. cit., ks. I, rozdz. 32, k. 122-123.

109 Ibidem, ks. II, rozdz. 85, k. 612.

110 Ibidem, ks. II, rozdz. 73, k. 593.

111 Ibidem, ks. I, rozdz. 26, k. 106.
} 
się narażać na represje ze strony przedstawicieli Kościoła za to, że szerzy herezje. $\mathrm{O}$ tym, że takie obawy mogły nie być bezpodstawne, świadczą procesy o czary, jakie w omawianym okresie były toczone w Europie Zachodniej, ale także w Polsce ${ }^{112}$.

Znamienna jest uwaga, która znalazła się w zielniku Spiczyńskiego. Ten autor zastrzegł, że dobre duchy będą ochraniać człowieka tylko wówczas, kiedy ten będzie ufał Bogu i wierzył w skuteczność przepisanego medykamentu ${ }^{113}$. Starał się - podobnie jak pozostali autorzy - łączyć wiedzę na temat ziół wywodzącą się z nauki okresu starożytnego z tradycją chrześcijańską, kładąc przy tym nacisk na konieczność wyznawania wiary w Boga. Zbliżone rozważania na temat zasadności porzucenia słowiańskich obyczajów wyraził Marcin z Urzędowa. Z dezaprobatą opisał przebieg słowiańskiego święta sobótki, które przypadało na św. Jana. Kobiety „tam też w nocy ognie paliły, tańcowały, śpiewały diabłu cześć a modłę czyniąc. Tego obyczaju pogańskiego do tych czasów w Polscze nie chcą opuszczać niewiasty, bo takież to ofiarowanie tego ziela czynią, wieszając, opasując się niem. Święta też tey diablicy święcą, czyniąc sobotki, paląc ognie, krzesząc ogień deskami, aby była prawa świętość diabelska: tamże śpiewają diabelskie pieśni, plugawe, tańcując, a diabeł też skacze, raduje się, że mu krześcijanie czynią modłę a chwałę, a o miłego Boga nie dbają, abowiem dzień Świętego Jana wieśniaków przy chwale miłego Boga żadnego nie będzie, a około sobótki będą wszyscy czynić rozmaite złości”"114.

112 Por. K. Baschwitz, Czarownice. Dzieje procesów o czary, tłum. T. Zabłudowski, Warszawa 1999, s. 124-141; R. Bugaj, Nauki tajemne w dawnej Polsce - Mistrz Twardowski, Wrocław 1986, s. 126-129; J. Kracik, Chrześcijanistwo kontra magia. Historyczne perypetie, Kraków 2012, s. 171-180; É. Lévi, Historia magii, tłum. J. Prokopiuk, Warszawa 2000, s. 263-267; M. Pilaszek, Procesy o czary w Polsce w wiekach XV-XVIII, Kraków 2008, passim; J. Wijaczka, Kościót wobec czarów w Rzeczypospolitej w XVI-XVIII wieku (na tle europejskim), Warszawa 2016, passim.

113 H. Spiczyński, op. cit., O wódkach ziót rozmaitych, p. 100v.

114 Marcin z Urzędowa, op. cit., cap. XXXIIII, k. 32. 


\section{Podsumowanie}

W zielnikach znajduje się sporo informacji na temat praktyk magicznych, które były stosowane przy leczeniu rozmaitych dolegliwości zarówno fizycznych, jak i psychicznych. Zdecydowanie najwięcej interesujących mnie danych znalazło się w zielniku Szymona Syreniusza. Autor ten umieścił informacje na temat tego, w jaki sposób chronić się przed urokami, czartami, złymi duchami, nieczystymi i utrapionymi duszami. Analiza renesansowych zielników wykazała, że podczas czynności magicznych wykorzystywano różnorodne metody, aby móc osiągnąć oczekiwany rezultat. Zwracano uwagę na wpływ ciał niebieskich i znaków zodiaku, a co się z tym wiąże, także na czas pozyskiwania materiału zielarskiego. Efekt magiczny starano się uzyskać przez sadzenie konkretnych roślin wokół domostw, rozkładanie ich w przestrzeni domu, bezpośrednio na posłaniu, sypanie suszonych i startych na proch ziół między ludźmi, polewanie ludzi naparem lub wódką ziołową.

Dopiero wykonanie konkretnych czynności warunkowało skuteczność leczenia. Do praktyk z pogranicza magii należało dotykanie i zrywanie ziół, patrzenie na zioła o niecodziennych właściwościach, trzymanie ich w ręku, przykładanie zaczarowanemu, stałe noszenie przy sobie w formie wieńca czy pierścienia albo w obuwiu. Zdecydowanie najwięcej przepisów na walkę z czarną magią zakładało noszenie magicznych roślin przy sobie, bezpośrednio na ciele bądź w formie zawieszek na szyi lub paciorków robionych z ziół i miodu ${ }^{115}$. Niekiedy zwracano uwagę na to, by nosić zioła tak, aby dotykały gołego ciała. Podobnych rezultatów spodziewano się też w wyniku wąchania olejków eterycznych ulatniających się z odpowiednich roślin i wskutek wdychania dymu wydzielanego z palonych suszonych roślin. Praktykowano również polewanie lub omywanie ciała w magicznych ziołach, kąpiel całego ciała, smarowanie roztworami wodnymi lub alkoholowymi oraz sokiem, robienie okładów ${ }^{116}$ i przykładanie plastrów. Stosowano także picie naparów i odwarów ziołowych, wódek ziołowych, soku z konkretnych ziół, jedzenie zup z zawartością leczniczych roślin, picie ziół moczonych w occie, piwie lub winie.

115 Sz. Syreniusz, op. cit., ks. I, rozdz. 26, k. 106.

116 Ibidem, ks. II, rozdz. 4, k. 365. 
Autorzy zielników nie zawsze pisali, które części rośliny należy wykorzystywać do praktyk magicznych. Czasami pojawiała się informacja o korzeniach, nasionach bądź liściach, ale najczęściej używane było ziele, czyli część naziemna rośliny. Niekiedy wystarczała sama obecność ziół w pobliżu, aby można było wykorzystywać ich pozytywny, ochronny wpływ na człowieka. Nie zabrakło rad mających na celu ustrzeżenie ludzi przed szkodliwym działaniem roślin. Dla przykładu cień rzucany przez cis miał razić jadem, a nawet przyczyniać się do śmierci człowieka, dlatego należało unikać stawania w cieniu tego drzewa lub krzewu ${ }^{117}$. Do czynności magicznych używano także fragmentów zwierząt, jednak przepisów na ich stosowanie jest zdecydowanie mniej.

W zielnikach silnie uwidaczniają się akcenty podnoszące znaczenie guseł, zamawiań, wróżb, zabobonów, czarów i snów jako elementów, które były niezmiennie obecne w codziennym życiu w omawianym okresie. Dla autorów herbarzy podawanie recept mających zapobiec czarom, uchronić ludzi przed rzuceniem klątwy lub stanowiących antidotum w przypadku, kiedy ktoś uległ czarom, było czymś oczywistym, wpisującym się w rzeczywistość, w której żyli. Przykłady użycia praktyk magicznych przez medyków pokazują, że były one obecne nie tylko w medycynie ludowej, ale również w gronie wykształconych lekarzy.

Mimo mnogości przekazów na temat obecności praktyk magicznych w życiu ówcześnie żyjących ludzi w zielnikach można znaleźć jedynie nieliczne informacje, w jaki sposób były zadawane czary, kogo dotykały najbardziej i w jakich okolicznościach były rzucane. Niekiedy autorzy zielników zaznaczali, iż czerpią wiedzę na temat czarownych właściwości ziół, sposobów na odczarowanie kogoś lub zabezpieczenie przed urokiem od autorów antycznych, częściej jednak takiej informacji nie było, co pozwala domniemywać, że w tych wypadkach odwoływali się do polskiej kultury i tradycji ludowej.

117 Marcin z Urzędowa, op. cit., cap. LXXXIX, k. 384-385; Sz. Syreniusz, op. cit., ks. V, rozdz. 105, k. 1391. Istniało przeświadczenie, że cis łączy się ze śmiercią, dlatego sadzono go na miejscach spoczynku, wierząc, że będzie odstraszał złe duchy i samego diabła. Dzisiaj wiadomo, że cis ma taksynę, trujący alkaloid; M. I. Macioti, Mity i magie ziót, tłum. I. Kania, Kraków 2006, s. 91. 